\title{
The Chloride Anion Acts as a Second Messenger in Mammalian Cells - Modifying the Expression of Specific Genes
}

\author{
Ángel G. Valdivieso Mariángeles Clauzure Macarena Massip-Copiz \\ Tomás A. Santa-Coloma
}

\begin{abstract}
Laboratory of Cellular and Molecular Biology, Institute for Biomedical Research (BIOMED), School of Medical Sciences, Pontifical Catholic University of Argentina (UCA) and The National Scientific and Technical Research Council of Argentina (CONICET), Buenos Aires, Argentina
\end{abstract}

\section{Key Words}

Intracellular chloride • Second messenger - GLRX5 - RPS27 • Chloride-dependent gene expression

\begin{abstract}
Background/Aims: Cystic Fibrosis (CF) is caused by mutations in the CFTR gene, encoding a cAMP-activated chloride $\left(\mathrm{Cl}^{-}\right)$channel. We have previously demonstrated that the expression of several genes can be modulated by the CFTR activity; among them, SRC, MTND4, CISD1, and ILIB. However, the CFTR signalling mechanism involved in the expression of CFTRdependent genes is unknown. The aim of this work was to determine if intracellular chloride $(\mathrm{Cl}) \mathrm{i}$ might function as a second messenger modulating the expression of specific genes. Methods: Differential display (DD) was applied to IB3-1 cells (CF cells), cultured under conditions that produce different intracellular $\mathrm{Cl}^{-}$concentrations $([\mathrm{Cl}-] \mathrm{i})$, to analyse their expression profile. Results: Several differentially expressed gene products were observed by using $D D$, suggesting the presence of chloride-dependent gene expression. Two CDNA fragments, derived from differentially expressed mRNAs and showing opposed response to $\mathrm{Cl}^{-}$, were isolated, cloned, sequenced and its $\mathrm{Cl}^{-}$dependency validated by reverse transcription quantitative-PCR (RT-qPCR). We identified the gene RPS27, which encodes the multifunctional ribosomal protein RPS27, also known as metallopanstimulin-1 (MPS-1), and the gene GLRX5, encoding glutaredoxin-related protein 5, as chloride-dependent genes. RPS27 was negatively regulated with increased [Cl-]i, approximately from $25-75 \mathrm{mM} \mathrm{Cl}^{-}\left(\mathrm{EC}_{50}=46 \pm 7 \mathrm{mM}\right)$, and positively regulated from $75-125 \mathrm{mM} \mathrm{Cl}^{-}\left(E_{50}=110 \pm 11 \mathrm{mM}\right)$ (biphasic response). In contrast, GLRX5 was positively modulated by $\left[\mathrm{Cl}^{-}\right] \mathrm{i}$, showing a typical sigmoidal dose-response curve

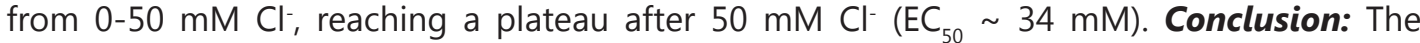
results suggest the existence of chloride-dependent genes. The $\mathrm{Cl}^{-}$anion, therefore, might act as a second messenger for channels or receptors able to modulate the intracellular $\mathrm{Cl}^{-}$ concentration, regulating in turn the expression of specific genes.




\section{Cellular Physiology Cell Physiol Biochem 2016;38:49-64 \\ \begin{tabular}{ll|l} 
and Biochemistry & $\begin{array}{l}\text { DOI: 10.1159/000438608 } \\
\text { Published online: January 08, } 2016\end{array}$ & $\begin{array}{l}\text { ( ) 2016 The Author(s). Published by S. Karger AG, Basel } \\
\text { www.karger.com/cpb }\end{array}$ \\
\hline
\end{tabular} \\ Valdivieso et al.: Chloride Anion as a Second Messenger}

\section{Introduction}

CFTR (Cystic Fibrosis Transmembrane Conductance Regulator) mutations are the cause of cystic fibrosis (CF)[1]. The complex phenotypic characteristics of CF differ in patients that carry different mutations, and often there is not a direct correlation between genotype and phenotype [2, 3]. CFTR is an integral membrane glycoprotein located in the apical region of epithelial cells. Initially identified as a cAMP-activated chloride transporter [4], was later found to be also involved in ATP transport. However, the CFTR direct or indirect role in the release of ATP is a controversial matter [5-9]. More recently, the CFTR channel has been also associated to glutathione [10] and bicarbonate [11] transport. In addition, in a pig model of $\mathrm{CF}$, the reduced bicarbonate transport that occurs as a consequence of the impaired CFTR activity, resulted in a reduced $\mathrm{pH}$ of the airway surface liquid (ASL); this effect might be in turn responsible for the increased susceptibility to bacterial infections [12-14].

In an attempt to explain the complex phenotype observed in CF, we hypothesize about the possible existence of a net of genes under CFTR control (CFTR-dependent genes). This hypothesis was corroborated by using differential display (DD) $[15,16]$. In this way, several CFTR-dependent genes were characterized, including SRC and MUC1 [16], CISD1 [17], and MTND4 [18-20]. Regarding c-Src, its activity and expression were found increased in cultured CF cells with impaired CFTR activity, and linked to MUC1 protein overexpression [16]. Thus, c-Src was the first intermediate molecule found for the CFTR signaling pathway. These results suggest that CFTR should possess a signaling mechanism responsible for the activation of c-Src and other CFTR-dependent genes.

The exact mechanisms/pathways by which CFTR transduce a signal that regulates the CFTR-dependent genes are not well established. Both, the presence of the CFTR in the plasma membrane and its intrinsic chloride channel activity appear to be involved as independent signaling mechanisms. In the first case, at least for the expression of RANTES, the signal transduction has been reported as originated in the association between the CFTR consensus PDZ interacting domain T-K/R-L (C-terminal) [21] and the PDZ domain-containing protein EBP50 (NHERF) [22]. Interestingly, this mechanism appears to be independent of the CFTR channel activity, since inhibitors of CFTR-mediated chloride transport had no effects on RANTES expression [22]. In the second case, the chloride transport activity of CFTR was found to be involved, since differential gene expression could be observed in cells treated with different CFTR inhibitors (NPPB, glibenclamide, CFTR(inh)-172), as occurred with $c$-Src, MTND4, CISD1 and IL1B [16, 17, 20, 23].

After c-Src, we characterized two additional CFTR-dependent genes, CISD1 (nuclear genome) and MTND4 (mitochondrial genome). Noteworthy, both genes encoded for mitochondrial proteins, having a decreased expression in CF cells [17, 20]. Since MTND4 was essential for the assembly and activity of the mitochondrial Complex I ( $\mathrm{mCx}$-I), we then tested its activity in CF cells and, accordingly, a reduced mCx-I activity was found in CF cells compared to rescued cells [19]. Later we found that IL-1 $\beta$ was also a CFTR-dependent gene, and that an autocrine loop of this cytokine was responsible for the increased ROS production and the reduced $\mathrm{mCx}$ - I activity found in CF cells [23]. On the other hand, by using microarrays analysis, other laboratories also found differentially expressed genes in CF cells, although without further analysis [24-27]. Therefore, the existence of CFTR-dependent genes has been well established.

Now, since normally CFTR secrete chloride and the intracellular chloride concentration ([Cl] $]$ i) increases in the presence of CFTR inhibitors [28], we hypothesized that $\mathrm{Cl}^{-}$could be the first element in the CFTR signaling mechanism, acting as a second messenger in the modulation of specific genes. Thus, as a first approach, the aim of this work was to demonstrate that changes in [Cl-]i might modulate the expression of specific genes. In agreement with this idea, the results obtained here suggest that $\mathrm{Cl}^{-}$is able to modulate the expression (steadystate levels) of specific genes, demonstrating the existence of chloride-dependent genes in mammalian cells, and suggesting that $\mathrm{Cl}^{-}$may function as a second messenger for channels/ receptors that modulate the intracellular $\mathrm{Cl}^{-}$concentration. 


\section{Cellular Physiology Cell Physiol Biochem 2016;38:49-64

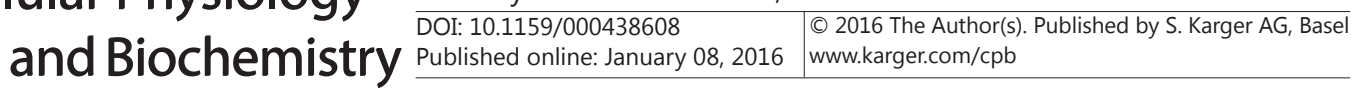 Valdivieso et al.: Chloride Anion as a Second Messenger}

\section{Materials and Methods}

Cultured cells

IB3-1 cells were used (ATCC CRL-2777 cells, discontinued; now, this cell line is part of the Johns Hopkins University Special Collection items). IB3-1 cells are bronchial epithelial cells derived from a CF patient (heterozygote containing $\triangle \mathrm{F} 508$ and $\mathrm{W} 1282 \mathrm{X}$ mutations), immortalized by using the hybrid adenovirus adeno-12-SV40 [29]. Cells were cultured in DMEM/F12 (Life Technologies, GIBCO BRL, Rockville, MD) supplemented with 10 \% FBS (Internegocios S.A., Mercedes, Buenos Aires, Argentina), 100 $\mathrm{U} / \mathrm{ml}$ penicillin and $100 \mu \mathrm{g} / \mathrm{ml}$ streptomycin (Life Technologies, GIBCO BRL, Rockville, MD). Cultures were grown at $37{ }^{\circ} \mathrm{C}$ in a humidified air atmosphere containing $5 \% \mathrm{CO}_{2}$. All cells were plated at a density of $15 \mathrm{x}$ $10^{3}$ cells $/ \mathrm{cm}^{2}$, and cultured by using $5 \mathrm{ml}$ of media in p100 plates $\left(\sim 80 \mu \mathrm{l} \mathrm{media/} \mathrm{cm}^{2}\right)$. Before the assays, the cells were cultured $24 \mathrm{~h}$ in serum-free DMEM/F12.

\section{Differential display}

Differential display of mRNA was carried out essentially as described by Liang and Pardee [30, 31], with modifications that allowed us to avoid false positive results [15], and to work without radioactive labeling [32]. IB3-1 cells were incubated for $1 \mathrm{~h}$ in the presence of different $\mathrm{Cl}^{-}$concentrations ([Cl-]) (25, $50,100$ and $140 \mathrm{mM})$. To establish a rapid equilibrium between the intracellular $\mathrm{Cl}^{-}$concentration $\left(\left[\mathrm{Cl}^{-}\right]\right.$ i) and the extracellular chloride concentration $\left(\left[\mathrm{Cl}^{-}\right] \mathrm{e}\right)$, independently of chloride channel activities, a double-ionophore strategy was used [33]. Briefly, IB3-1 cells were washed with Hank's-gluconate (Table 1), to remove the remaining extracellular $\mathrm{Cl}$, and then incubated for $1 \mathrm{~h}$ with different extracellular chloride concentrations $\left[\mathrm{Cl}^{-}\right]$e. The different $\mathrm{Cl}^{-}$concentrations were obtained combining two high $\mathrm{K}^{+}$buffers (High- $\mathrm{KCl}$ and High- $\mathrm{KNO}_{3}$ Table 1), containing the ionophores nigericin $(5 \mu \mathrm{M})$ and tributyltin $(10 \mu \mathrm{M})$ (Sigma-Aldrich, St. Louis, MO). To obtain the different $\mathrm{Cl}^{-}$concentrations, this anion was replaced by $\mathrm{NO}_{3}$. As shown in Table 2 , the osmolalities, measured by using a vapor pressure osmometer (Wescor Inc., Logan, Utah, model 5500), did not differed significantly $(\mathrm{p}<0.05)$ except for the higher concentration of $140 \mathrm{mM}$. Therefore, the results obtained at $140 \mathrm{mM}$ might also represent a response to osmotic stress and should be taken with caution. After incubation, total RNA was isolated by using the guanidinium thiocyanate-phenol method described by Chomczynski et al. [34]. Reverse transcription (RT) was performed by using $4 \mu \mathrm{g}$ of total RNA, M-MLV reverse transcriptase (100 U, Promega, Madison, WI) and $8 \mu \mathrm{M}$ of the anchored $5^{\prime}-\mathrm{T}_{12}(\mathrm{ACG}) \mathrm{T}-3^{\prime}$ primer, in a $25 \mu \mathrm{l}$ final reaction volume, according to manufacturer's instructions. The reaction was performed for 90 $\min$ at $37{ }^{\circ} \mathrm{C}, 5 \mathrm{~min}$ at $75^{\circ} \mathrm{C}$, and then cooled to $4{ }^{\circ} \mathrm{C}$. The synthesized cDNAs were used immediately for PCR amplifications, or stored at $-80^{\circ} \mathrm{C}$ for later use. The DD-PCR reactions were performed in a final volume reaction of $25 \mu \mathrm{l}$, containing a final concentration of $1 \mathrm{mM} \mathrm{MgCl}_{2}, 0.1 \mathrm{mM}$ deoxynucleotides triphosphates,

Table 1. Composition of buffers used

\begin{tabular}{lcccc}
\hline Composition (mM) & Hank's-Cl & Hank's-gluconate & High-KCl & High-KNO 3 \\
\hline $\mathrm{NaCl}$ & 136.9 & 0 & 0 & 0 \\
$\mathrm{KCl}$ & 5.4 & 0 & 140 & 0 \\
$\mathrm{KNO}_{3}$ & 0 & 0 & 0 & 140 \\
$\mathrm{CaCl}_{2}$ & 1.3 & 0 & 0 & 0 \\
$\mathrm{Na}_{\text {gluconate }}$ & 0 & 136.9 & 0 & 0 \\
Ca-gluconate & 0 & 1.3 & 1.3 & 1.3 \\
$\mathrm{~K}_{\text {gluconate }}$ & 0 & 5.4 & 0 & 0 \\
$\mathrm{NaH}_{2} \mathrm{PO}_{4}$ & 3.7 & 3.7 & 3.7 & 3.7 \\
$\mathrm{KH}_{2} \mathrm{PO}_{4}$ & 0.4 & 0.4 & 0.4 & 0.4 \\
$\mathrm{NaHCO}_{3}$ & 4.2 & 4.2 & 4.2 & 4.2 \\
$\mathrm{MgSO}_{4}$ & 0.7 & 0.7 & 0.7 & 0.7 \\
$\mathrm{D}$-glucose & 5.5 & 5.5 & 5.5 & 5.5 \\
$\mathrm{HEPES}$ & 10 & 10 & 10 & 10 \\
\hline
\end{tabular}




\section{Cellular Physiology Cell Physiol Biochem 2016;38:49-64

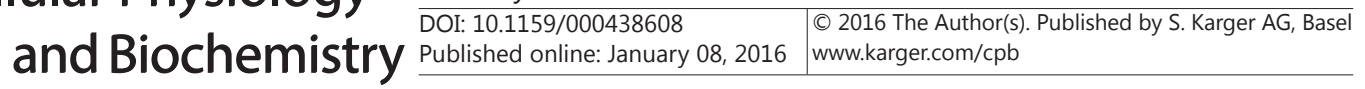 Valdivieso et al.: Chloride Anion as a Second Messenger}

1 unit of GoTaq DNA polymerase (Promega), $10 \mu \mathrm{l}$ of cDNA (from $1 / 50$ dilution), $1 \mu \mathrm{M}$ of 20 different 10 mer random primers (RAPDs kit B primers, acquired from Byodinamics SRL, Buenos Aires, Argentina, containing 20 different random primers; each primer was used to obtain an independent DD reaction), and $2 \mu \mathrm{M} 5^{\prime}-\mathrm{T}_{12}$ (ACG)T-3' as reverse primer. The PCR conditions were: denaturation at $94^{\circ} \mathrm{C} 5 \mathrm{~min}$, and 40 cycles of $94{ }^{\circ} \mathrm{C}(30 \mathrm{~s}), 40^{\circ} \mathrm{C}(2 \mathrm{~min})$, and $72{ }^{\circ} \mathrm{C}(30 \mathrm{~s})$. A final extension for $5 \mathrm{~min}$ at $72{ }^{\circ} \mathrm{C}$ was then performed. Aliquots of $5 \mu \mathrm{l}$ of each amplification product were mixed with equal amount of loading buffer (10 mM NaOH, 0.05\% bromophenol blue, 0.05\% xylene cyanol, $95 \%(\mathrm{v} / \mathrm{v})$ formamide), heated at $90{ }^{\circ} \mathrm{C}$ for 3 min, and chilled on ice until loaded in a $6 \%$ polyacrylamide sequencing gel. A pre-running at 90 Watts (constant potency)
Table 2. Osmolality of the different $\mathrm{Cl}$ concentration obtained. by combining the High- $\mathrm{KCl}$ and High- $\mathrm{KNO}_{3}$ solutions

\begin{tabular}{cc}
\hline $\begin{array}{c}{[\mathrm{Cl}]} \\
(\mathrm{mM})\end{array}$ & $\begin{array}{c}\text { Osmolality } \\
(\mathrm{mOsm} / \mathrm{Kg} \pm \text { SEM, } \mathrm{n}=4)\end{array}$ \\
\hline 0 & $293.5 \pm 1.5$ \\
5 & $292.8 \pm 1.0$ \\
25 & $292.5 \pm 0.5$ \\
50 & $294.3 \pm 1.8$ \\
75 & $296.8 \pm 0.9$ \\
100 & $295.5 \pm 1.6$ \\
125 & $296.8 \pm 1.4$ \\
140 & $301.5 \pm 1.5$ \\
\hline
\end{tabular}

was performed in TBE $1 \mathrm{X}$ buffer (0.1 M Tris Base, $0.1 \mathrm{M}$ boric acid, $2 \mathrm{mM}$ EDTA), until the gel temperature in the electrophoresis equipment (Model STS45, IBI Kodak, New Haven, CT) reached $50-55^{\circ} \mathrm{C}$. The wells were then loaded with $3 \mu \mathrm{l}$ of each amplification product, and the gel was run for $150 \mathrm{~min}$. The cDNA bands were then visualized by silver staining, as was previously described by Caetano-Anoles et al. [32].

\section{Cloning and identification of differential expressed bands}

The differential expressed bands were excised from the DD gel, purified from agarose gels, PCR reamplified, cloned into a pGEM-T vector (Promega), and transformed in E. coli DH5 $\alpha$ competent cells as previously described [35]. Colony PCRs [36] were performed using T7 (5'-TAATACGACTCACTATAGGG-3') and SP6 (5'-TATTTAGGTGACACTATAGAATA-3') primers, and the plasmids from insert-positive colonies were selected, amplified, purified by using a mini-prep kit (Promega), and sequenced (sequencing core facility at the School of Exact and Natural Sciences from the University of Buenos Aires). The BLAST program $[37,38]$ (National Center for Biotechnology Information) was used to identify the sequences corresponding to the cloned cDNA fragments.

\section{Reverse transcription-real time $q P C R$}

Reverse transcription-real time qPCRs (RT-qPCR) were used to validate the DD results [19] and for the determination of the effects of different intracellular chloride concentrations $\left(\left[\mathrm{Cl}^{-}\right] \mathrm{i}\right)$ on gene expression. Total RNA samples (2 $\mu \mathrm{g}$ ) were obtained from IB3-1cells incubated for $1 \mathrm{~h}$ at different extracellular $\mathrm{Cl}^{-}$ concentrations $(0,5,25,50,100$ and $140 \mathrm{mM})$, in the presence of nigericin $(5 \mu \mathrm{M})$ and tributyltin $(10$ $\mu \mathrm{M})$. The RNA quality was checked by electrophoresis in denaturing formaldehyde agarose gels [39], and measuring the ratios A260/A230 (greater than 2) and A260/A280 nm (from 1.7 to 2.0). The RNA was reverse transcribed by using M-MLV reverse transcriptase (Promega), according to the manufacturer's instructions with some modifications. Briefly, $100 \mathrm{U}$ of M-MLV reverse transcriptase, $2 \mu \mathrm{g}$ RNA, $8 \mu \mathrm{M}$ Oligo-dT and 2 mM dNTPs were used for reverse transcription. The software Primer-BLAST (http://blast.ncbi.nlm.nih. gov/Blast.cgi) [40] was used to design primers for GLRX5 (Fw-(GLRX5) 5'-TACGCGGCCTACAACGTGCT-3', Rv-(GLRX5) 5'-CAGCCCCCTACA AACTCGCCA-3') and RPS27 (Fw-(RPS27) 5'-GGCGGTGACGACCTACGCAC-3', Rv-(RPS27) 5'-TAGCATCCTGGGCATTTCACATCCA-3'). The GLRX5 expression was referred to GAPDH expression, while the RPS27 expression was referred to $18 S$ rRNA expression, due to the high level of expression observed for RPS27. The primers for GAPDH were: Fw-(GAPDH) 5'-TGCACCACCAACTGCTTAGC-3' and Rv-(GAPDH) 5'-GGCATGGACTGTGGTCATGAG-3' [41], and the primers for 18S rRNA were: Fw-(18S) 5'-CCGATAACGAACGAGACTCTGG-3' and Rv-(18S) 5'-TGAACGCCACTTGTCCCTCTAAG-3' [42]. RT-qPCRs were performed by using an ABI 7500 real-time PCR system (Applied Biosystems Inc., Foster City, CA), and the $\triangle \triangle \mathrm{Ct}$ method was used to obtain the expression levels relative to GAPDH or $18 \mathrm{~S}$ rRNA expression, by using software from Applied Biosystems. The size of each amplification product and the absence of dimers were verified by electrophoresis on $3 \%$ agarose gels, stained with ethidium bromide, and visualized by using an UV transilluminator (UVP BioDoc-It, Upland, CA) as previously described [23]. Then, preliminary experiments with different cDNA dilutions were performed to test the dynamic range and efficiency of amplification [43] for each amplicon (GLRX5, GAPDH, RPS27 and 18S). The $\triangle \triangle \mathrm{Ct}$ analysis was performed only when the efficiency of amplification was over $85 \%$. The cDNA samples (10 $\mu \mathrm{l}$ of a 1:25 cDNA dilution) were added to 


\section{Cellular Physiology Cell Physiol Biochem 2016;38:49-64

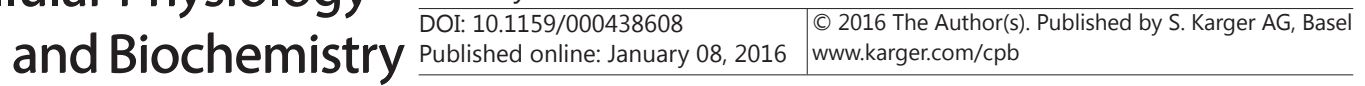 \\ Valdivieso et al.: Chloride Anion as a Second Messenger}

$15 \mu \mathrm{l}$ of PCR reaction mixture containing a final concentration of $2.5 \mathrm{mM} \mathrm{MgCl}{ }_{2}, 0.5 \mathrm{mM}$ deoxynucleotides triphosphates, $1 \mathrm{U}$ of GoTaq DNA polymerase (Promega), 0.4 X EvaGreen (Biotium, Hayward, CA), and $50 \mathrm{nM}$ ROX (Sigma-Aldrich) as passive reference dye [19]. For GLRX5 amplifications, $0.5 \mu \mathrm{M}$ of each primer were used, for GAPDH, $0.3 \mu \mathrm{M}$, and for $18 \mathrm{~S}$ ribosomal RNA and RPS27 $0.2 \mu \mathrm{M}$. PCR conditions were: denaturation at $94^{\circ} \mathrm{C}(5 \mathrm{~min})$, and 40 cycles of $94^{\circ} \mathrm{C}(30 \mathrm{~s}), 60^{\circ} \mathrm{C}(30 \mathrm{~s})$, and $72{ }^{\circ} \mathrm{C}(30 \mathrm{~s})$.

Measurement of the intracellular chloride concentration ([Cl-]i) in the presence of ionophores

To test whether the equilibrium between the [Cl]]i and the extracellular chloride concentration ([Cl- $]$ e) was correctly established in our experimental conditions, the [Cl-] in IB3-1 cells, incubated in the presence of different concentration of chloride and ionophores (tributyltin $10 \mu \mathrm{M}$ and nigericin $5 \mu \mathrm{M}$ ), was measured by using SPQ (6-methoxy-N-[3-sulfopropyl]quinolinium) (Invitrogen, Carlsbad, CA) [33, 44], and fluorescence spectrophotometry, as we described previously [45]. Briefly, cells seeded at a density of 25,000 cells $/ \mathrm{cm}^{2}$, were grown to confluence over rectangular coverslips (22 x $8 \mathrm{~mm}$, Hitachi, Japan), in 6 wells plates, using $3 \mathrm{ml}$ of DMEM/F12 containing FBS 5\%. The coverslips were pre-treated with a coating solution $(10 \mu \mathrm{g} /$ $\mathrm{ml}$ fibronectin, $4.4 \mu \mathrm{g} / \mathrm{ml}$ collagen, $1.5 \mu \mathrm{g} / \mathrm{ml} \mathrm{BSA}$ in DMEM/F12) for $1 \mathrm{~h}$ and then washed with serum free DMEM/F12. After reaching confluence, the cells were loaded O.N. with $5 \mathrm{mM}$ SPQ in the same medium. The SPQ-loaded monolayers were washed five times with $3 \mathrm{ml}$ of Hank's-chloride buffer (Table 1). Covers with the cells were mounted in a holder especially modified to allow perfusion of the cells, and the fluorescence was measured as previously detailed [45]. First, the initial fluorescence $\mathrm{F}_{0}$ was measured after fluorescence equilibration in High- $\mathrm{KNO}_{3}$ buffer (without chloride), in the presence of ionophores. Then, High-K buffers, containing different $\mathrm{Cl}^{-}$concentration and constant amount of ionophores, were perfused to calculate the Stern-Volmer constant $\left(\mathrm{K}_{\mathrm{C}}\right)$. At each measurement point the flow rate was stopped to allow reaching homogeneity into the perfusion chamber and to reach equilibrium between the intracellular [Cl-]i and the extracellular $\left[\mathrm{Cl}^{-}\right]$e chloride concentrations. The $\left[\mathrm{Cl}^{-}\right]$e achieved in the perfusion chamber at equilibrium was calculated from the internal standard fluorescence (fluorescein dye), as previously described [45]. After equilibration, values were recorded for $60 \mathrm{~s}$ and the average value for each calculated $\mathrm{Cl}^{-}$concentration was used to obtain the Stern-Volmer plot $\left(\mathrm{F}_{0} / \mathrm{F}=1+\mathrm{K}_{\mathrm{Cl}}\left[\mathrm{Cl}^{-}\right]\right)$. In this equation, $\mathrm{F}_{0}$ is the $\mathrm{SPQ}$ fluorescence measured in the absence of $\mathrm{Cl}^{-}$( $\mathrm{SPQ}$ inside the cells), and $\mathrm{F}$ is the fluorescence at each chloride concentration. The Stern-Volmer constant $\mathrm{K}_{\mathrm{Cl}}\left(\mathrm{M}^{-1}\right)$, corresponding to the intracellular chloride, was calculated from the slope obtained from a linear regression fit. Each fluorescence point was recorded to calculate later the $\left[\mathrm{Cl}^{-}\right] \mathrm{i}$, by applying the Stern-Volmer equation $\left[\mathrm{Cl}^{-}\right]=\left(\mathrm{F}_{0} / \mathrm{F}\right)-1 / \mathrm{K}_{\mathrm{Cl}}$ and these values were then used to plot $\left[\mathrm{Cl}^{-}\right]_{\mathrm{i}} \mathrm{vs}\left[\mathrm{Cl}^{-}\right]_{\mathrm{e}}$.

\section{In silico analyses and predictions}

BLAST searches were used to determine the identity of the sequences corresponding to the isolated fragments from the differential display [38]. The matching protein sequences were obtained from the NCBI data bank (http://www.ncbi.nlm.gov). For multiple sequence alignments, the Clustal Omega software was used; protein sequences from different species were aligned [46]. The PROSITE database [47], and the NCBI Conserved Domain Database (CDD) tools (www.ncbi.nlm.nih.gov/Structure) [48] were used to identify protein conserved domains. To predict possible phosphorylation sites within the protein sequences, the software NetPhos 2.0 [49], DISPHOS 1.3 [50] and PhosphoSite Plus [51] were used. Only the coincident results from the three packages were shown. The representation of the 3D structure was made by using the software Discovery Studio 4.0 (accelrys.com) [52] and the PDB data file corresponding to GLRX5 (PDB: 2WUL). Pathway Studio v 10 (Elsevier) was used to perform literature searches, the analysis of the involved molecules and proteins, and to draw the graphic illustrating the results.

\section{Statistics}

Unless otherwise indicated, all the assays were performed by duplicates and the experiments were repeated at least three times (biological replicates $n=3$ ). RT-qPCR reactions were carried out by using intraassay quadruplicates (technical replicates $n=4$ ). The final RT-qPCR quantification values were obtained as the means of the relative quantification (RQ) values for each independent experiment $(n=3)$. The different curves and regression were fitted by using the software Origin (OriginLab Co.) and the $\mathrm{R}^{2}$ values were used to obtain the Student's t value and the corresponding $p$ value. $\left({ }^{*}=\mathrm{p}<0.05\right.$ was considered significant). Then, ANOVA and Tukey tests were performed to determine the significant differences among means, indicated by the symbol* $(\mathrm{p}<0.05)$. 


\section{Cellular Physiology Cell Physiol Biochem 2016;38:49-64 \begin{tabular}{ll|l} 
and Biochemistry 10.1159/000438608 & $\begin{array}{l}\text { (c) 2016 The Author(s). Published by S. Karger AG, Basel } \\
\text { www.karger.com/cpb }\end{array}$ \\
\hline
\end{tabular} \\ Valdivieso et al.: Chloride Anion as a Second Messenger}

\section{Results}

Changes in the intracellular chloride concentration modulate the expression of specific genes

Differential display (DD) was applied to test the hypothesis that the intracellular chloride concentration $\left(\left[\mathrm{Cl}^{-}\right]_{\mathrm{i}}\right)$ might modulate the expression of specific genes. IB3-1 CF cells were incubated for $1 \mathrm{~h}$ in the presence of two different high-potassium (high-K) buffers (Table 1) combined to produce increased extracellular chloride concentrations $([\mathrm{Cl}] \mathrm{e})$. As shown in Table 2, the osmolality of the different $\mathrm{Cl}^{-}$solutions do not differ significantly (292-296 $\mathrm{mOsm} / \mathrm{Kg}$ ) except for the solution at $140 \mathrm{mM} \mathrm{Cl}^{-}(301.5 \pm 1.5 \mathrm{mOsm} / \mathrm{Kg}, \mathrm{p}<0.05)$. To reach a rapid equilibrium between $\left[\mathrm{Cl}^{-}\right] \mathrm{e}$ and $\left[\mathrm{Cl}^{-}\right] \mathrm{i}$, independently of the CFTR activity or other chloride channels, tributyltin (a $\mathrm{Cl}^{-} / \mathrm{OH}^{-}$exchanger) and nigericin $\left(\mathrm{K}^{+} / \mathrm{H}^{+}\right.$exchanger) were added to the High-K buffers. Tributyltin equilibrates $\mathrm{Cl}^{-}$across the membrane, and nigericin, in presence of high $\mathrm{K}^{+}$, clamps the intracellular $\mathrm{pH}$ to the extracellular $\mathrm{pH}$ value while $\mathrm{Cl}^{-}$ ] changes. This double ionophore strategy is usually employed as a method to measure [Cl]i [33]. Nigericin/tributyltin treatment for 10-15 min was sufficient to equilibrate the intracellular and extracellular chloride concentration, as it was previously reported [33]. In order to test the experimental conditions, the equilibrium between $\left[\mathrm{Cl}^{-}\right] \mathrm{e}$ and $\left[\mathrm{Cl}^{-}\right]$ i was followed by using SPQ. The SPQ fluorescence of IB3-1 cells, in the presence of the ionophores, was monitored at different $\left[\mathrm{Cl}^{-}\right]$e. As shown in Figure 1A, an exponential decay of SPQ fluorescence occurs in the presence of increased chloride concentrations. The SternVolmer (SV) plot [33] obtained from the data shown in Figure 1A were used to calculate the SV constant $\left(\mathrm{K}_{\mathrm{SV}}=17.14 \pm 2.3\right.$, mean $\pm \mathrm{SEM}, \mathrm{n}=3$, inter-assay), and the same data and

Fig. 1. Correlation between the intracellular and extracellular chloride concentration. A) Calibration curve corresponding to the SPQ chloride-sensitive fluorescent dye obtained in IB3-1 cells incubated for $1 \mathrm{~h}$ in the presence of different chloride concentrations (0-140 $\mathrm{mM})$, tributyltin $(10 \mu \mathrm{M})$ and nigericin $(5 \mu \mathrm{M})$, to rapidly equilibrate the intracellular chloride concentration. B) Intracellular chloride concentrations $\left(\left[\mathrm{Cl}^{-}\right] \mathrm{i}\right)$ measured in IB3-1 cells vs. the extracellular chloride ([Cl-]e) concentration. The graph shows a good correspondence between intra- and extracellular chloride concentrations (lineal correlation with slope $=1, \mathrm{R}^{2}=0.96, \mathrm{t}=16.9, \mathrm{DF}=12, \mathrm{p}$ $<0.001$ ), implying that the equilibrium was reached within $1 \mathrm{~h}$.

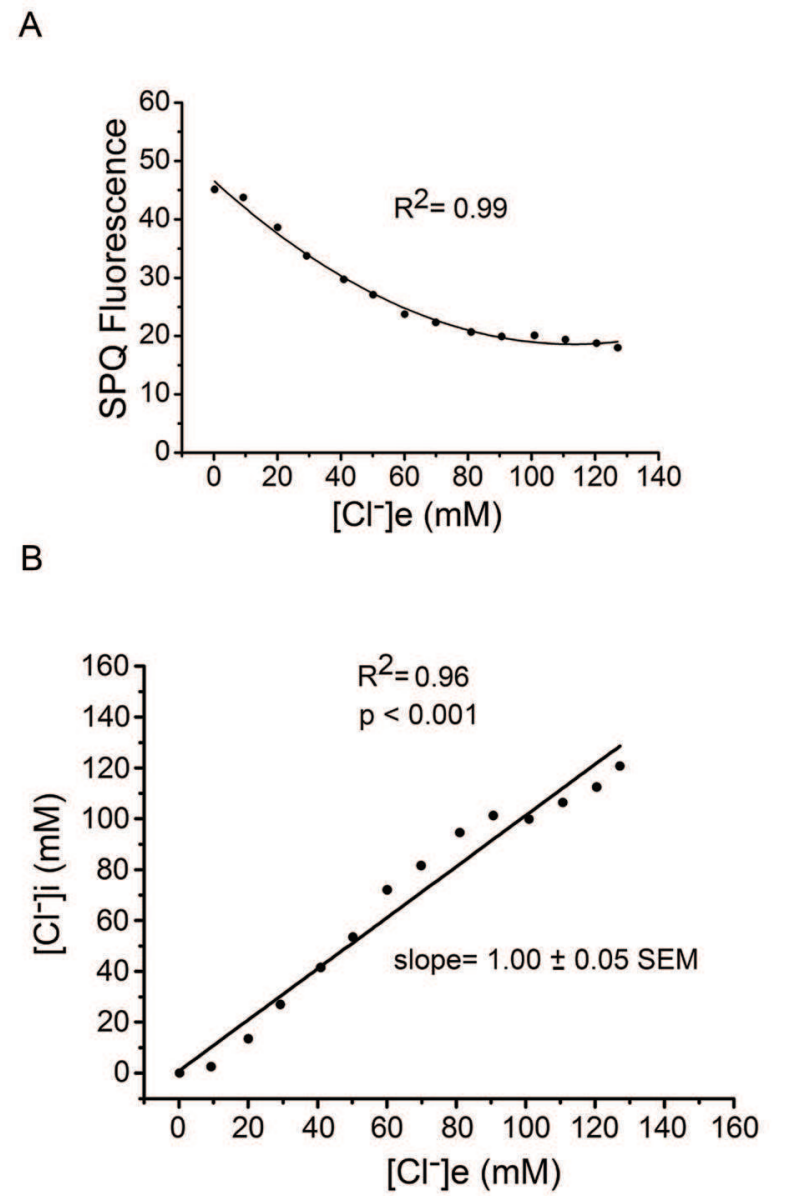




\section{Cellular Physiology Cell Physiol Biochem 2016;38:49-64 \begin{tabular}{ll|l} 
DOI: 10.1159/000438608 & $\begin{array}{l}\text { @ 2016 The Author(s). Published by S. Karger AG, Basel } \\
\text { www.karger.com/cpb }\end{array}$ \\
\hline
\end{tabular} \\ Valdivieso et al.: Chloride Anion as a Second Messenger}

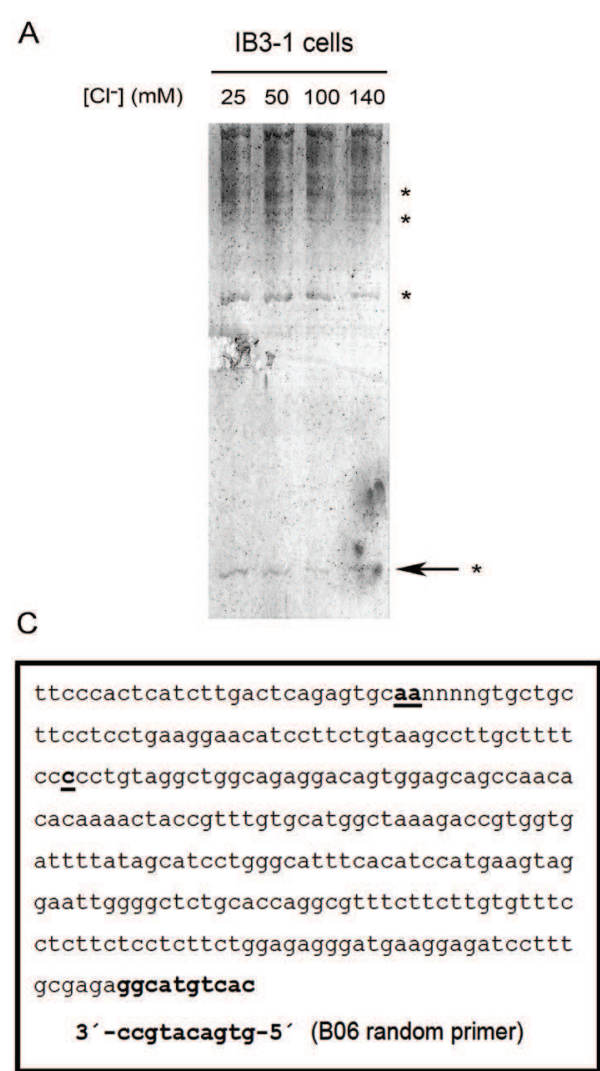

B

\begin{tabular}{lllll} 
& \multicolumn{4}{c}{ IB3-1 cells } \\
\cline { 2 - 5 }$\left[\mathrm{Cl}^{-}\right](\mathrm{mM})$ & 25 & 50 & 100 & 140 \\
\cline { 2 - 5 } & & & & \\
\hline
\end{tabular}

b

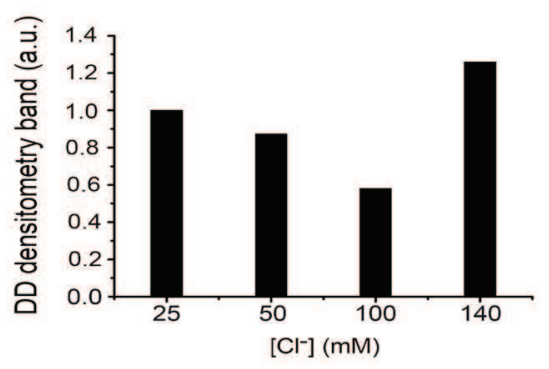

$\mathrm{D}$

Fig. 2. Differential display (DD) identifying RPS27 as a chloride-dependent gene. A) DD obtained from cultured IB3-1 cells, incubated at different chloride concentrations $(25,50,100$ and $140 \mathrm{mM})$ in the presence of the ionophores nigericin $(5 \mu \mathrm{M})$ and tributyltin $(10 \mu \mathrm{M})$, for $1 \mathrm{~h}$. The symbols * show differential expressed bands and the arrow indicates the band selected for analysis, cloning and sequencing. Ba) Magnification of the selected band. Bb) Densitometry of Ba plotted in arbitrary units (a.u.) vs. [ $\left.\mathrm{Cl}^{-}\right] \mathrm{i}$. A tendency towards a biphasic response vs. [Cl-] was observed. C) Sequence of the cDNA fragment isolated from the DD gel, identified as RPS27. The primers used are indicated in bold and polymorphisms are underlined in bold. D) BLAST alignment of the sequence fragment isolated from the DD. This fragment showed $99 \%$ identity to human RPS27. Differences in the sequence, possibly due to polymorphisms, are indicated in red letters.

the $\mathrm{SV}$ equation $[\mathrm{Cl}] \mathrm{i}=(\mathrm{F} 0 / \mathrm{F})-1 / \mathrm{K}_{\mathrm{Cl}}$ was used to plot $\left[\mathrm{Cl}^{-}\right] \mathrm{i}$ vs [Cl-]e. As shown in Figure $1 \mathrm{~B}$, a significant linear regression between the $\left[\mathrm{Cl}^{-}\right] \mathrm{i}$ and $\left[\mathrm{Cl}^{-}\right] \mathrm{e}$ was found (linear fit, $\mathrm{R}^{2}=0.96$, slope $=1.00 \pm 0.05$, mean $\pm S E M, n=3, p<0.001$ ), indicating that the ionophores were working properly and that $[\mathrm{Cl}]$ e and $[\mathrm{Cl}]$ i were equilibrated.

The DD results obtained by using different random primer sets indicated the presence of several differentially expressed gene products. Figure 2 exemplify this, showing the expression pattern obtained with one out of 20 random primers (the forward primer $5^{\prime}$-GTGACATGCC-3' and the oligo-dT anchored primer 5'-T12(ACG)T-3'). Here, the intensity of several cDNA fragments changed with increased chloride concentrations $(*$ and arrows in Fig. 2A), suggesting the presence of chloride-dependent gene expression. One of these bands (cDNA fragments), corresponding to a differentially expressed gene, was selected for further analysis (band indicated by an arrow in Fig. 2A). A magnification of the selected band is shown in Figure 2Ba and its quantification by densitometry vs. [Cl-]e in shown in Figure 2Bb. This spot was of interest since it showed a biphasic response against the different chloride concentrations. The cDNA fragment corresponding to this band was isolated from the DD gel, cloned and sequenced (Fig. 2C). A BLAST search showed 99\% identity compared to 


\section{Cellular Physiology Cell Physiol Biochem 2016;38:49-64 \begin{tabular}{ll|l} 
DOI: 10.1159/000438608 & $\begin{array}{l}\text { @ 2016 The Author(s). Published by S. Karger AG, Basel } \\
\text { www.karger.com/cpb }\end{array}$ \\
\hline
\end{tabular} \\ Valdivieso et al.: Chloride Anion as a Second Messenger}

A

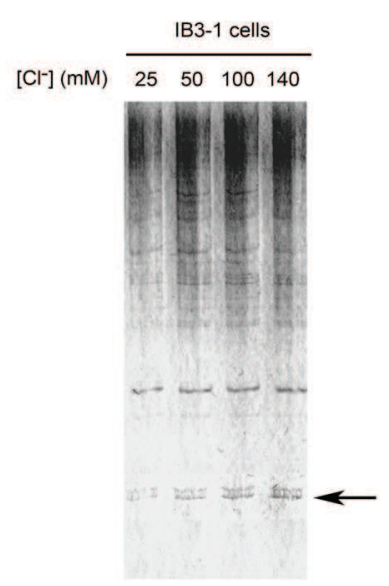

C
B

\begin{tabular}{ccccc} 
& \multicolumn{4}{c}{ IB3-1 cells } \\
\cline { 2 - 5 }$[\mathrm{Cl}-](\mathrm{mM})$ & 25 & 50 & 100 & 140 \\
\cline { 2 - 5 } & & &
\end{tabular}

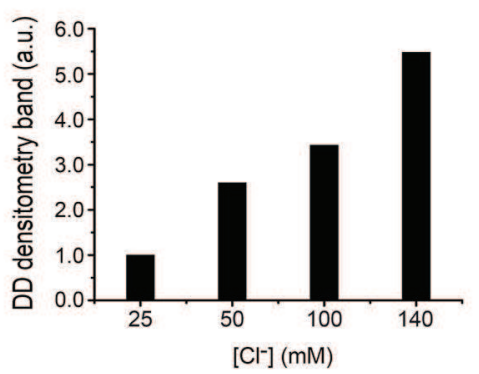

D

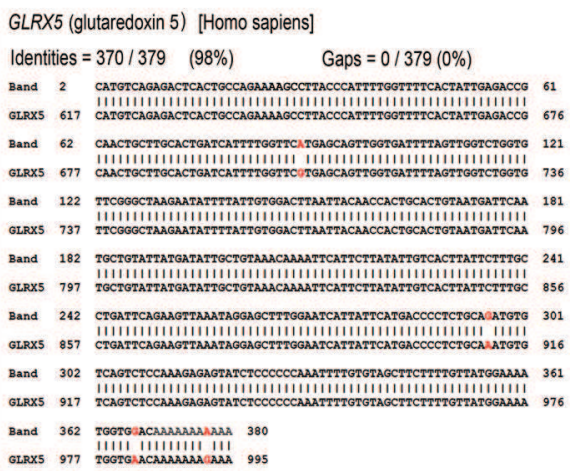

Fig. 3.Differential display (DD) identifying GLRX5 as a chloride-dependent gene. A) DD obtained from IB3-1 cells incubated at different chloride concentrations (25, 50, 100 and $140 \mathrm{mM})$, in the presence of the ionophores nigericin $(5 \mu \mathrm{M})$ and tributyltin $(10 \mu \mathrm{M})$, for $1 \mathrm{~h}$. The arrow indicates the differential expressed band selected for further analysis, cloning and sequencing. Ba) Magnification of the selected band. Bb) Quantitation of the selected band, expressed in arbitrary units (a.u) vs. [ $\left.\mathrm{Cl}^{-}\right]$. A tendency towards increased expression vs. [ $\left.\mathrm{Cl}^{-}\right]$was observed. C) Sequence of the cDNA fragment isolated from the DD gel, corresponding to the GLRX5 gene. The primers used are indicated in bold and possible polymorphisms are underlined in bold. D) BLAST alignment of the sequence corresponding to the fragment isolated from the DD. This fragment shows 98\% identity compared to human GLRX5 (glutaredoxin 5). Differences are shown in red.

the Homo sapiens RPS27 gene, encoding the 40S ribosomal protein S27 (NM_001030, gene symbol RPS27, also named metallopanstimulin 1,MPS-1,S27), a multifunctional protein that was found over-expressed in some cancer cell lines [41,53-55], which is also an structural constituent of the ribosome [56].

Figure $3 \mathrm{~A}$ illustrates the expression pattern obtained using another random primer (5'-GCATGTCAGA-3' (B02) and the oligo-dT anchored primer $5^{\prime}-\mathrm{T}_{12}$ (ACG)T-3'), in the presence of different chloride concentrations ([Cl] $\sim[\mathrm{Cl}] \mathrm{i}$, also by using the ionophores). The arrow indicates a band that, contrary to the band shown in Figure 2A, was up-regulated by chloride in a dose-dependent manner. Figure 3Ba shows a magnification of the selected band that was then quantified by densitometry and plotted as relative intensity vs $\left[\mathrm{Cl}^{-}\right] \mathrm{e}$ (Fig. 3Bb). This differentially expressed cDNA fragment was isolated from the gel, cloned and sequenced. The sequence (Fig. 3C) was used as an input for BLAST (http://blast.ncbi. nlm.nih.gov/) using the Reference RNA sequence (refseq_rna) database, and the sequence found, aligned with the query sequence, is shown in Fig. 3D. The sequence has $98 \%$ identity to human glutaredoxin 5 (GLRX5) mRNA (NM 016417.2 ). 


\section{Cellular Physiology Cell Physiol Biochem 2016;38:49-64 \begin{tabular}{ll|l} 
and Biochemistry $10.1159 / 000438608$ & $\begin{array}{l}\text { C 2016 The Author(s). Published by S. Karger AG, Basel } \\
\text { www.karger.com/cpb }\end{array}$ \\
\hline
\end{tabular} \\ Valdivieso et al.: Chloride Anion as a Second Messenger}

Fig. 4. Validation of the Differential Display results by using quantitative real-time PCR. Validation of DD results for RPS27 (A) and GLRX5 (B). Their expression levels were measured by using RT-qPCR performed on total RNA extracted from IB3-1 cells incubated at increased chloride concentrations, in the presence of the ionophores nigericin $(5 \mu \mathrm{M})$ and tributyltin $(10 \mu \mathrm{M})$ for $1 \mathrm{~h}$ (conditions identical to those used to obtain the DD). The results are expressed in arbitrary units (a.u.), taken the value corresponding to $0 \mathrm{mM}$ chloride as 1 . Measurement were performed in three (RPS27) or four (GLRX5) independent experiments (biological replicates), each done at least in duplicates (technical replicates). The RPS27 expression values vs. [ $\left.\mathrm{Cl}^{-}\right]$were adjusted by using a $4^{\text {th }}$ order polynomial curve, and then by two sigmoidal curves to obtain the $\mathrm{EC}_{50}$ (from 5-75 mM one sigmoidal curve and from 75-125 mM the second). The GLRX5 expression was adjusted by using a sigmoidal dose-response curve. A Student's test (t-test) was applied to determine the significance of the fitting curves, obtaining the $t$ value from the $\mathrm{R}^{2}$ value (RPS27, polynomial fit $\mathrm{R}^{2}=0.94, \mathrm{t}=5.6$, degrees of freedom $\mathrm{DF}=2, \mathrm{p}<0.05$, inter-assay n $=3$; GLRX5, sigmoidal fit $\mathrm{t}=12.1, \mathrm{DF}=3, \mathrm{p}<0.001$, inter-assay $\mathrm{n}$ $=4$ ). ${ }^{*}$ indicate $\mathrm{p}<0.05$ between means connected through a line.

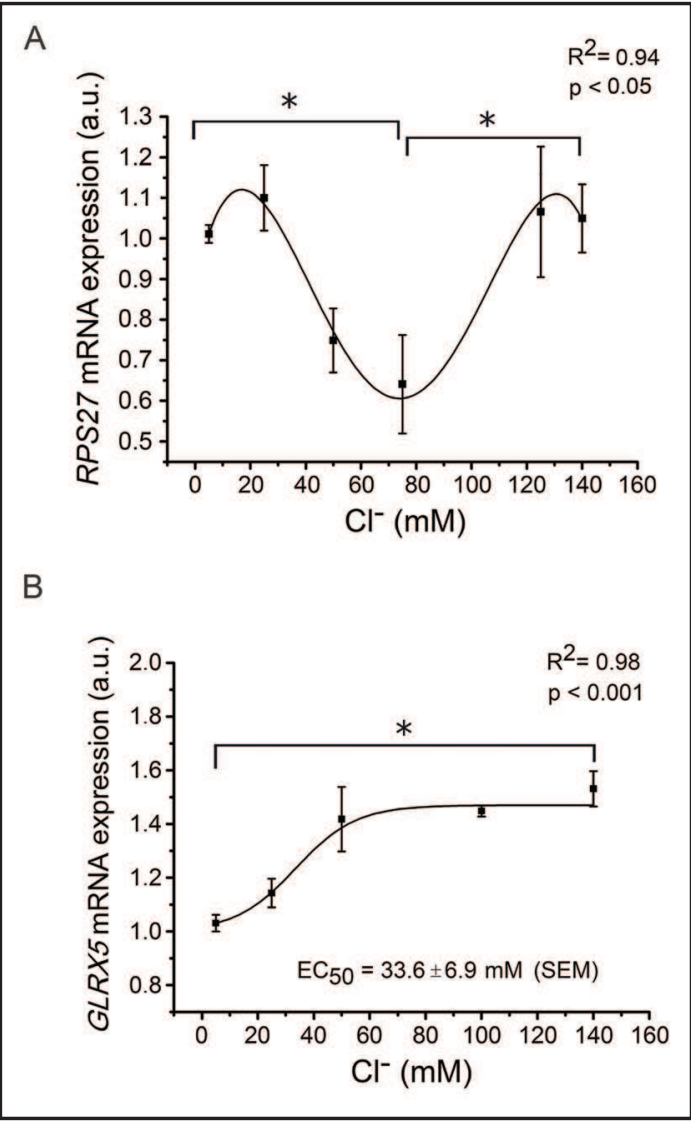

Validation of the DD results by using RT-qPCR

To validate the DD results a different set of specific primers were synthesized (selected by using primer-BLAST http://www.ncbi.nlm.nih.gov/tools/primer-blast/), and used for reverse transcription quantitative-PCR (RT-qPCR). RPS27 and GLRX5 expressions were measured in cultured IB3-1 cells incubated at different concentrations of chloride, in the presence of tributyltin and nigericin ionophores. As shown in Figure 4A, in agreement with the DD results, the RPS27 expression showed a biphasic modulation in response to increased [Cl] $]$ i $\left(4^{\text {th }}\right.$ order polynomial fit, $\mathrm{R}^{2}=0.94, \mathrm{p}<0.05$ ) with maximal expression levels at 25 and $125 \mathrm{mM}$. The maximal down-regulation of this gene was observed at $75 \mathrm{mM}[\mathrm{Cl}-] \mathrm{i}$. Thus, the mRNA steady-state level of this gene is negatively modulated in the range $25-75 \mathrm{mM}\left(\mathrm{EC}_{50}\right.$ $=47 \pm 7 \mathrm{mM}, \mathrm{SEM}, \mathrm{n}=2)$ and positively modulated in the range $75-125 \mathrm{mM}\left(\mathrm{EC}_{50}=110 \pm 11\right.$ $\mathrm{mM}, \mathrm{SEM}, \mathrm{n}=2$ ). Also in agreement with the DD results, a dose-response curve was obtained for the GLRX5 expression vs. [Cl-]e (Fig. 4B). Maximal expression was observed at $50 \mathrm{mM}$ [Cl-] $\mathrm{e}$, reaching a plateau after this concentration $\left(\mathrm{EC}_{50}=33.6 \pm 6.9 \mathrm{mM}, \mathrm{SEM} ; \mathrm{n}=4\right.$; sigmoidal fit, $\mathrm{t}=12, \mathrm{DF}=3, \mathrm{p}<0.001, \mathrm{R}^{2}=0.98$ ).

\section{In silico analysis}

In silico analyses for RPS27 and GLRX5 were performed to illustrate the main characteristics of these genes (Fig. 5). RPS27 encodes for a ribosomal protein of 84 amino acids (aa) (protein sequence found by using BLAST [38]; Fig. 5Aa). As shown in Figure $5 \mathrm{Ba}$, this protein was highly conserved through different species (NCBI Conserved Domain Database (CCD) CD-Search tool (www.ncbi.nlm.nih.gov/Structure) [48]). The only change was observed at aa 11 in Xenopus, where an $\mathrm{S}$ was substituted for a T, a putative site for phosphorylation, as predicted by NetPhos 2.0 [49], DISPHOS 1.3 [50] and PhosphoSite Plus [51] (Fig. 5Ca). The analysis for conserved domains (CDD database) indicates that this protein belongs to de Ribosomal 27e superfamily, having a zinc finger domain that span from 


\section{Cellular Physiology Cell Physiol Biochem 2016;38:49-64 \begin{tabular}{ll|l} 
and Biochemistry Published online: January 08, 2016 & $\begin{array}{l}\text { ○ 2016 The Author(s). Published by S. Karger AG, Basel } \\
\text { www.karger.com/cpb }\end{array}$ \\
\hline
\end{tabular}
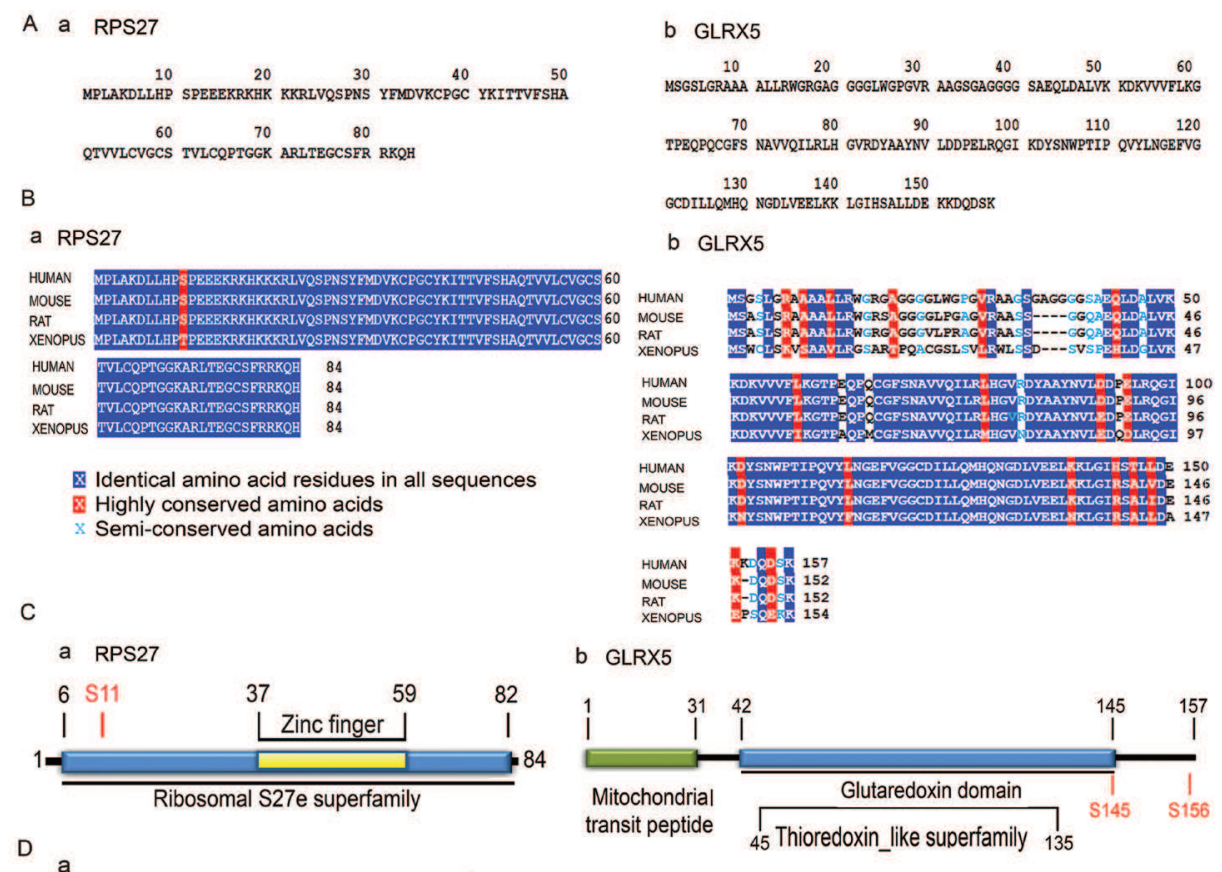

b GLRX5

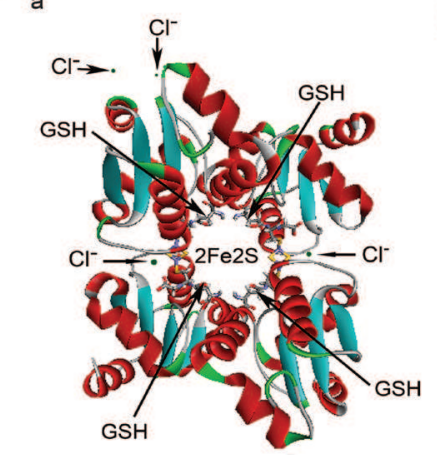

b
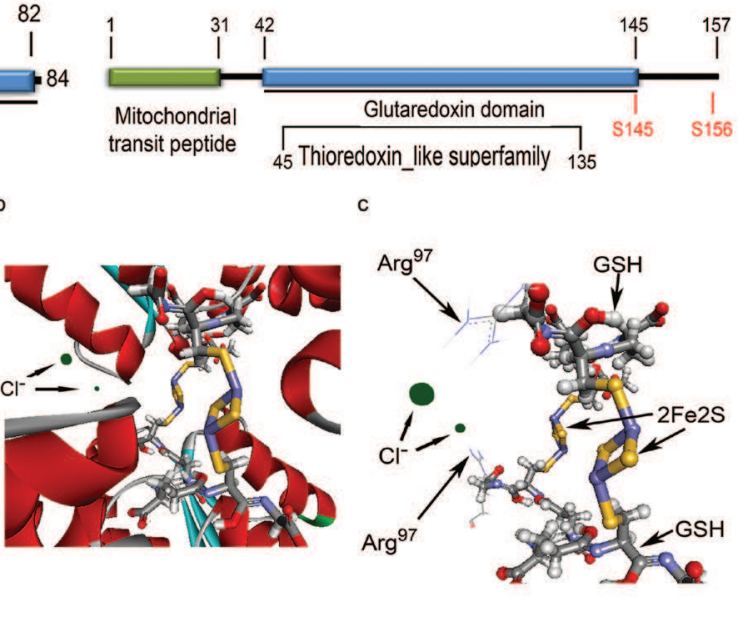

Fig. 5. In silico analysis. Aa) Amino acid (aa) sequence for RPS27 ( $84 \mathrm{aa}$ ). Ab) aa sequence for GLRX5 (157 aa). B) BLAST search identifying RPS27 (Ba) and GLRX5 (Bb) protein homologs and conserved domains. The corresponding Ortholog proteins from rat, mouse and xenopus showed a high degree of identity in both cases, GLRX5 and RPS27. C) Representation of conserved domains and putative phosphorylation sites. Ca) The RPS27 aa region 6-82 constitutes a conserved domain characteristic of the Ribosomal S27e superfamily, and the region 37-59 constitutes a zinc finger domain. $\mathrm{Cb}$ ) The mitochondrial transit peptide for GLRX5, which spans from aa 1-31, and the glutaredoxin domain comprising aa 42-145 are shown. The region containing aa 45-135 represents the conserved domain for the Thioredoxin_like superfamily. One phosphorylation site for RPS27 in S-11, and two phosphorylation sites for GLRX5 in S-147 and S-156 were predicted by using three different software packages (NetPhos 2.0, DISPHOS 1.3, and PhosphoSite Plus). Da) Tetrameric organization of human GLRX5, containing two (2Fe-2S) clusters, four glutathione (GSH) molecules, and four chloride ions. $\mathrm{Db}$ ) Active site of GLRX5 tetramer represented laterally to show the proximity of two $\mathrm{Cl}^{-}$ions. Dc) Backbone representation of the cluster [2Fe2S] coordinated by four GSH molecules; two chloride molecules facing the $2 \mathrm{Fe} 2 \mathrm{~S}$ are also shown, together with the lateral chain of Arg97 involved in GSH coordination, near to chloride anions.

aa 37-59 (Fig. 5Ca). The high sequence conservation among species suggests an important role for this protein, and that minor changes in the structure may affect its function [41].

On the other hand, the GLRX5 $\mathrm{Cl}^{-}$-dependency was of interest to us since its protein product has a structure and location similar to CISD1, a CFTR-dependent gene previously 


\section{Cellular Physiology \\ Cell Physiol Biochem 2016;38:49-64 \\ \begin{tabular}{ll|l} 
and Biochemistry & $\begin{array}{l}\text { DOI: 10.1159/000438608 } \\
\text { Published online: January 08, } 2016\end{array}$ & $\begin{array}{l}\text { () 2016 The Author(s). Published by S. Karger AG, Basel } \\
\text { www.karger.com/cpb }\end{array}$ \\
\cline { 2 - 3 } Valdivieso et al: Choride Anion as a Second Messenger
\end{tabular}}

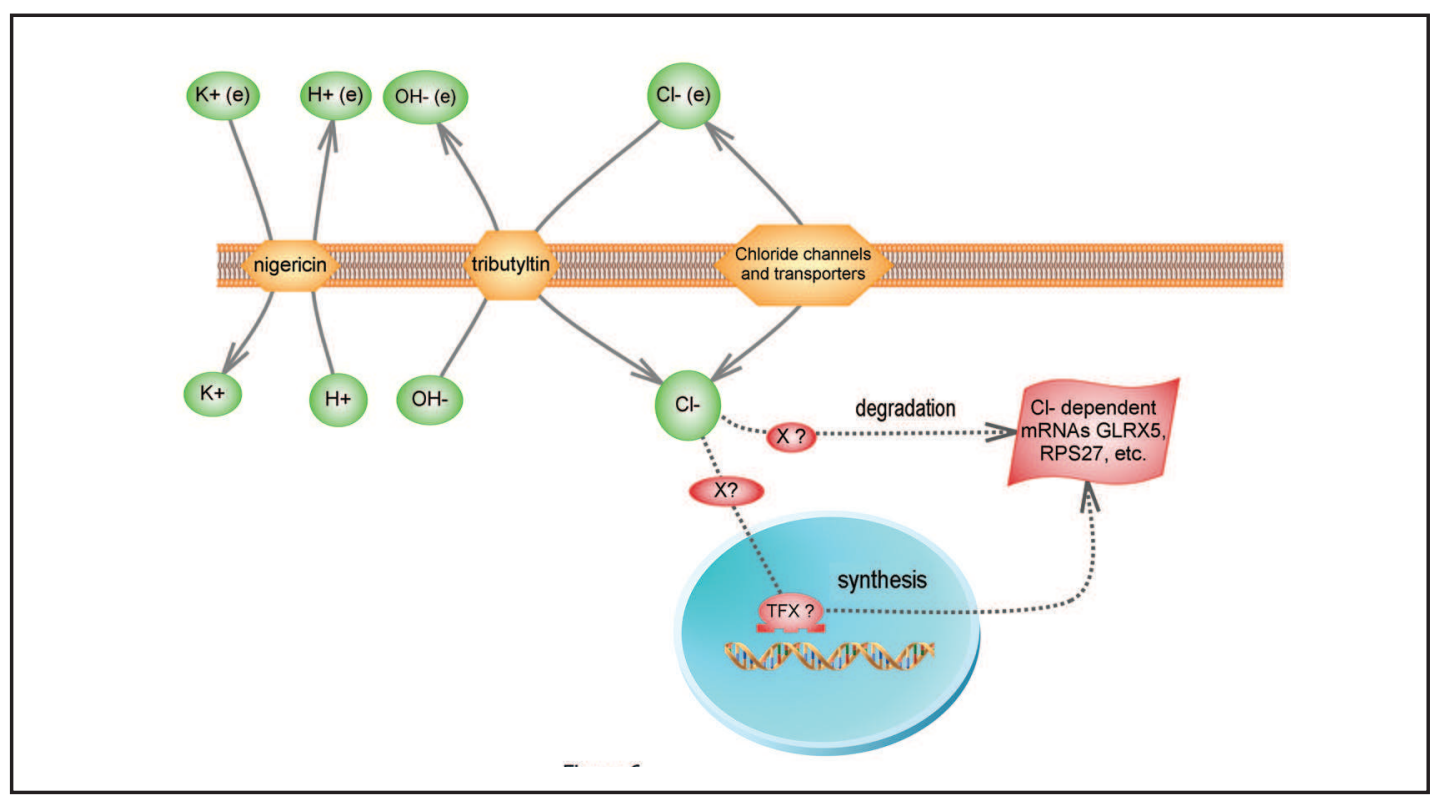

Fig. 6. Chloride-dependent gene expression. The graphic illustrates the results obtained demonstrating the existence of $\mathrm{Cl}^{-}$-dependent genes and suggesting a second messenger function for the $\mathrm{Cl}^{-}$anion. Alterations in the $\mathrm{Cl}^{-}$transport, leading to $\left.\mathrm{Cl}^{-}\right] \mathrm{i}$ changes, might be sensed by yet unidentified factors (X?) that regulate the expression of these genes. Further studies are needed to elucidate the mechanisms by which the $\mathrm{Cl}^{-}$anion acts as second messenger and modulates the expression of $\mathrm{Cl}^{-}$-dependent genes. TFX? indicates unknown transcription factors.

identified and cloned in our laboratory [17]. CISD1, like GLRX5, is an iron-sulfur mitochondrial protein containing a $2 \mathrm{Fe}-2 \mathrm{~S}$ cluster for which many different functions have been attributed $[57,58]$. GLRX5 is a nuclear gene (also CISD1) that encodes a mitochondrial protein of 157 amino acids (Fig. 5Ab), evolutionarily conserved among eukaryotes (Fig. 5Bb) [59]. Figure $5 \mathrm{Cb}$ illustrates the conserved domains obtained by using the NCBI Conserved Domain Database tool (http://www.ncbi.nlm.nih.gov/) [48]. GLRX5 also belongs to the glutaredoxin family (GRX) and the thioredoxin-like superfamily. As shown in Figure $5 \mathrm{Cb}$, the predicted mitochondrial transit peptide of GLRX5 spans from the aa 1 to 31 , while the glutaredoxin domain spans from aa 42 to 145 . On the other hand, possible phosphorylation sites were predicted by using the software NetPhos 2.0 [49], DISPHOS 1.3 [50] and PhosphoSite Plus [51], showing a common phosphorylation site for the aa S156 near the C-terminus. The tetrameric organization derived from crystal structure of human GLRX5, represented in Figure 5Da, contains two [2Fe-2S] clusters, four glutathione (GSH) molecules that contributes to the iron coordination, and four chloride ions $\left(\mathrm{Cl}^{-}\right)$[60]. Interestingly, two of the four $\mathrm{Cl}^{-}$ ions are in proximity of the active site (Fig. 5Db and c).

\section{Discussion}

Applying differential display to IB3-1 cells incubated in the presence of increased intracellular $\mathrm{Cl}^{-}$concentrations, we found several differentially expressed mRNAs. Two gel spots from the DDs were selected for further characterization, isolated from the gel, PCR amplified, purified, cloned, and sequenced. Their sequences corresponded to the ribosomal protein S27 (RPS27) and to glutaredoxin 5 (GLRX5). The chloride-dependency for the expression of these two genes was then confirmed by using RT-qPCR. The results suggest that changes in the [Cl]]i can modulate the expression of specific genes. A summary of the results obtained is illustrated in Figure 6. 


\section{Cellular Physiology Cell Physiol Biochem 2016;38:49-64 \begin{tabular}{ll|l|l} 
and Biochemistry $10.1159 / 000438608$ & $\begin{array}{l}\text { ( ) 2016 The Author(s). Published by S. Karger AG, Base } \\
\text { www.karger.com/cpb }\end{array}$ \\
\hline
\end{tabular} Valdivieso et al.: Chloride Anion as a Second Messenger}

It should be pointed-out that $R P S 27$ is positively regulated by $\mathrm{Cl}^{-}\left(\mathrm{EC}_{50}=110 \pm 11 \mathrm{mM}\right)$ within the range of 100-125 mM reported for CF cells [28], and negatively regulated ( $\mathrm{EC}_{50}$ $=47 \pm 7 \mathrm{mM}$ ) within a range reported for CFTR-activated FL-MDCK (flag labelled MadinDarby canine kidney) cells (basal $76 \pm 14 \mathrm{mM}$, cAMP-stimulated $36 \pm 8 \mathrm{mM}$ ) [61]. On the other hand, GLRX5 is positively regulated at a lower concentration ( $\mathrm{EC}_{50}=34 \pm 7 \mathrm{mM}$ ), also within the range of CFTR-activated FL-MDCK cells (36 $\pm 8 \mathrm{mM}$ [61]), reaching a plateau (unresponsive) at concentrations over $50 \mathrm{mM}$. We have not measured the protein levels of these two genes and we do not know if they might have a role in defining the CFTR phenotype. Alternatively, these genes might be involved in functions related to saline stress or other cellular responses that modify intracellular $\mathrm{Cl}^{-}$(e.g., response to GABA), unrelated to cystic fibrosis. The exact mechanisms for the regulation of chloride-dependent genes are unknown. These mechanisms could be multiple in nature and even using parallel pathways. The increased intracellular chloride concentration might, for example, induce changes in cell volume [62], perhaps triggering several pathways affecting gene regulation; therefore, some subset of chloride-dependent genes might change due to the cell volume modification induced by chloride. Thus, the chloride-dependency could be indirect and even involve different cellular processes and signaling pathways. However, in other cases the $\mathrm{Cl}^{-}$signaling might be more direct, modifying the activity of signaling molecules.

The possible role of $\mathrm{Cl}^{-}$as a second messenger has been previously suggested. In the bacterium Halobacillus halophilus, a chloride-regulon has been postulated to explain the chloride-dependency for the expression of fliC [63]. However, only the extracellular chloride concentration was changed in that study and the corresponding intracellular chloride concentration was not measured. On the other hand, the $\mathrm{Cl}^{-}$anion has been postulated as a second messenger in the regulation of many different enzymes and intracellular processes. It has a key role in regulation of different cellular functions and protein activities [62, 64-75], including $\mathrm{Na}^{+} / \mathrm{HCO}_{3}^{-}$transporters [76]. In this regard, a chloride-dependent phosphorylation has been found in the apical membrane of human epithelial cells [73]. More recently, Miyazaki et al. demonstrated that intracellular chloride could modulate the G1/S cell-cycle checkpoint by regulating the expression of p21, through modulation of stressactivated protein kinases $[77,78]$, and Treharne et al. [62] suggested the possible role of a $\mathrm{Cl}$-dependent phosphorylation cascade for CFTR signaling.

Taken together, the results obtained suggest the existence of chloride-dependent genes, and that $\mathrm{Cl}^{-}$might act as a second messenger able to modulate the expression of specific genes. This modulation can be positive, negative or biphasic, depending on the gene and the levels of intracellular chloride.

\section{Abbreviations}

CFTR (Cystic Fibrosis Transmembrane Conductance Regulator); CF (Cystic fibrosis); cAMP (adenosine-3'5'-cyclic monophosphate); DD (differential display); $\mathrm{mCx}-\mathrm{I}$ (mitochondrial Complex I); [Cl-]i (intracellular chloride concentration); [Cl-]e (extracellular chloride concentration); Cl- (chloride ions); RT-qPCR (reverse transcription quantitativePCR); GSH (glutathione); SPQ (6-methoxy-1-[3-sulfopropyl]quinolinium); DMSO (dimethylsulfoxide).

\section{Acknowledgments}

The technical assistant of María de Los Angeles Aguilar and the administrative assistant of Prof. Diego Battiato are acknowledged. This work was supported by National Agency for the Promotion of Science and Technology (ANPCYT) (grant numbers BID OC-AR 1728 PICT 2004-13970, PICT 2007-00628 and PICT 2012-1278) to TASC; National Scientific and Technical Research Council of Argentina (CONICET) (grants PIP 11220080102551 


\section{Cellular Physiology Cell Physiol Biochem 2016;38:49-64 \begin{tabular}{ll|l} 
and Biochemistry $10.1159 / 000438608$ & $\begin{array}{l}\text { C 2016 The Author(s). Published by S. Karger AG, Basel } \\
\text { www.karger.com/cpb }\end{array}$ \\
\hline
\end{tabular} Valdivieso et al.: Chloride Anion as a Second Messenger}

2009-2011 and PIP 11220110100685 2012-2014) to TASC; grants from Pontifical Catholic University of Argentina (UCA) to TASC and research fellowships from CONICET (to MMMC and MC), and from UCA (to AGV). Funding for open access charge was from Pontifical Catholic University of Argentina.

\section{Disclosure Statement}

The authors declare no financial or commercial conflict of interest.

\section{References}

1 Riordan JR, Rommens JM, Kerem B, Alon N, Rozmahel R, Grzelczak Z, Zielenski J, Lok S, Plavsic N, Chou JL, Drumm ML, Iannuzzi MC, Collins FS, Tsui LC: Identification of the cystic fibrosis gene: cloning and characterization of complementary DNA. Science 1989;245:1066-1073.

2 Collins FS: Cystic fibrosis: molecular biology and therapeutic implications. Science 1992;256:774-779.

3 Welsh MJ, Smith AE: Cystic fibrosis. Sci Am 1995;273:52-59.

4 Rommens JM, Dho S, Bear CE, Kartner N, Kennedy D, Riordan JR, Tsui LC, Foskett JK: cAMP-inducible chloride conductance in mouse fibroblast lines stably expressing the human cystic fibrosis transmembrane conductance regulator. Proc Natl Acad Sci U S A 1991;88:7500-7504.

5 Becq F: CFTR channels and adenosine triphosphate release: the impossible rendez-vous revisited in skeletal muscle. J Physiol 2010;588:4605-4606.

6 Cantiello HF: Nucleotide transport through the cystic fibrosis transmembrane conductance regulator. Biosci Rep 1997;17:147-171.

7 Prat AG, Reisin IL, Ausiello DA, Cantiello HF: Cellular ATP release by the cystic fibrosis transmembrane conductance regulator. Am J Physiol 1996;270:C538-545.

8 Reisin IL, Prat AG, Abraham EH, Amara JF, Gregory RJ, Ausiello DA, Cantiello HF: The cystic fibrosis transmembrane conductance regulator is a dual ATP and chloride channel. J Biol Chem 1994;269:2058420591.

9 Li C, Ramjeesingh M, Bear CE: Purified cystic fibrosis transmembrane conductance regulator (CFTR) does not function as an ATP channel. J Biol Chem 1996;271:11623-11626.

10 Kogan I, Ramjeesingh M, Li C, Kidd JF, Wang Y, Leslie EM, Cole SP, Bear CE: CFTR directly mediates nucleotide-regulated glutathione flux. Embo J 2003;22:1981-1989.

11 Chan HC, Shi QX, Zhou CX, Wang XF, Xu WM, Chen WY, Chen AJ, Ni Y, Yuan YY: Critical role of CFTR in uterine bicarbonate secretion and the fertilizing capacity of sperm. Mol Cell Endocrinol 2006;250:106113.

12 Chen JH, Stoltz DA, Karp PH, Ernst SE, Pezzulo AA, Moninger TO, Rector MV, Reznikov LR, Launspach JL, Chaloner K, Zabner J, Welsh MJ: Loss of anion transport without increased sodium absorption characterizes newborn porcine cystic fibrosis airway epithelia. Cell 2010;143:911-923.

13 Pezzulo AA, Tang XX, Hoegger MJ, Alaiwa MH, Ramachandran S, Moninger TO, Karp PH, Wohlford-Lenane CL, Haagsman HP, van Eijk M, Banfi B, Horswill AR, Stoltz DA, McCray PB, Jr., Welsh MJ, Zabner J: Reduced airway surface $\mathrm{pH}$ impairs bacterial killing in the porcine cystic fibrosis lung. Nature 2012;487:109-113.

14 Rogers CS, Stoltz DA, Meyerholz DK, Ostedgaard LS, Rokhlina T, Taft PJ, Rogan MP, Pezzulo AA, Karp PH, Itani OA, Kabel AC, Wohlford-Lenane CL, Davis GJ, Hanfland RA, Smith TL, Samuel M, Wax D, Murphy CN, Rieke A, Whitworth K, Uc A, Starner TD, Brogden KA, Shilyansky J, McCray PB, Jr., Zabner J, Prather RS, Welsh MJ: Disruption of the CFTR gene produces a model of cystic fibrosis in newborn pigs. Science 2008;321:1837-1841.

15 Cafferata EG, González-Guerrico AM, Pivetta OH, Santa-Coloma TA: Identification by differential display of a mRNA specifically induced by 12-0-tetradecanoylphorbol-13-acetate (TPA) in T84 human colon carcinoma cells. Cell Mol Biol (Noisy-le-grand) 1996;42:797-804. 


\section{Cellular Physiology Cell Physiol Biochem 2016;38:49-64

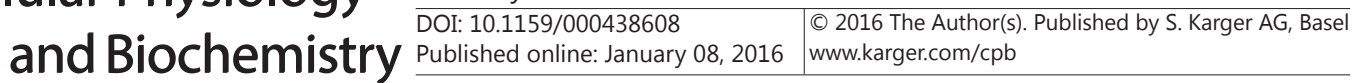 \\ Valdivieso et al.: Chloride Anion as a Second Messenger}

16 Gonzalez-Guerrico AM, Cafferata EG, Radrizzani M, Marcucci F, Gruenert D, Pivetta OH, Favaloro RR, Laguens R, Perrone SV, Gallo GC, Santa-Coloma TA: Tyrosine kinase c-Src constitutes a bridge between cystic fibrosis transmembrane regulator channel failure and MUC1 overexpression in cystic fibrosis. J Biol Chem 2002;277:17239-17247.

17 Taminelli GL, Sotomayor V, Valdivieso AG, Teiber ML, Marin MC, Santa-Coloma TA: CISD1 codifies a mitochondrial protein upregulated by the CFTR channel. Biochem Biophys Res Commun 2008;365:856862.

18 Valdivieso AG, Santa-Coloma TA: CFTR activity and mitochondrial function. Redox Biol DOI: 10.1016/j. redox.2012.11.007.

19 Valdivieso AG, Clauzure M, Marin MC, Taminelli GL, Massip Copiz MM, Sanchez F, Schulman G, Teiber ML, Santa-Coloma TA: The mitochondrial complex I activity is reduced in cells with impaired cystic fibrosis transmembrane conductance regulator (CFTR) function. PLoS One DOI: 10.1371/journal.pone.0048059.

20 Valdivieso AG, Marcucci F, Taminelli G, Guerrico AG, Alvarez S, Teiber ML, Dankert MA, Santa-Coloma TA: The expression of the mitochondrial gene MT-ND4 is downregulated in cystic fibrosis. Biochem Biophys Res Commun 2007;356:805-809.

21 Moyer BD, Duhaime M, Shaw C, Denton J, Reynolds D, Karlson KH, Pfeiffer J, Wang S, Mickle JE, Milewski M, Cutting GR, Guggino WB, Li M, Stanton BA: The PDZ-interacting domain of cystic fibrosis transmembrane conductance regulator is required for functional expression in the apical plasma membrane. J Biol Chem 2000;275:27069-27074.

22 Estell K, Braunstein G, Tucker T, Varga K, Collawn JF, Schwiebert LM: Plasma membrane CFTR regulates RANTES expression via its C-terminal PDZ-interacting motif. Mol Cell Biol 2003;23:594-606.

23 Clauzure M, Valdivieso AG, Massip Copiz MM, Schulman G, Teiber ML, Santa-Coloma TA: Disruption of interleukin-1beta autocrine signaling rescues complex I activity and improves ROS levels in immortalized epithelial cells with impaired cystic fibrosis transmembrane conductance regulator (CFTR) function. PLoS One DOI: 10.1371/journal.pone.0099257.

24 Eidelman 0, Zhang J, Srivastava M, Pollard HB: Cystic fibrosis and the use of pharmacogenomics to determine surrogate endpoints for drug discovery. Am J Pharmacogenomics 2001;1:223-238.

25 Srivastava M, Eidelman 0, Pollard HB: Pharmacogenomics of the cystic fibrosis transmembrane conductance regulator (CFTR) and the cystic fibrosis drug CPX using genome microarray analysis. Mol Med 1999;5:753-767.

26 Xu Y, Clark JC, Aronow BJ, Dey CR, Liu C, Wooldridge JL, Whitsett JA: Transcriptional adaptation to cystic fibrosis transmembrane conductance regulator deficiency. J Biol Chem 2003;278:7674-7682.

27 Voisin G, Bouvet GF, Legendre P, Dagenais A, Masse C, Berthiaume Y: Oxidative stress modulates the expression of genes involved in cell survival in DeltaF508 cystic fibrosis airway epithelial cells. Physiol Genomics 2014;46:634-646.

28 Guo JH, Chen H, Ruan YC, Zhang XL, Zhang XH, Fok KL, Tsang LL, Yu MK, Huang WQ, Sun X, Chung YW, Jiang $\mathrm{X}$, Sohma Y, Chan HC: Glucose-induced electrical activities and insulin secretion in pancreatic islet $\beta$-cells are modulated by CFTR. Nat Commun DOI: 10.1038/ncomms5420.

29 Zeitlin PL, Lu L, Rhim J, Cutting G, Stetten G, Kieffer KA, Craig R, Guggino WB: A cystic fibrosis bronchial epithelial cell line: immortalization by adeno-12-SV40 infection. Am J Respir Cell Mol Biol 1991;4:313-319.

30 Liang P, Averboukh L, Pardee AB: Distribution and cloning of eukaryotic mRNAs by means of differential display: refinements and optimization. Nucleic Acids Res 1993;21:3269-3275.

31 Liang P, Pardee AB: Differential display of eukaryotic messenger RNA by means of the polymerase chain reaction. Science 1992;257:967-971.

32 Caetano-Anolles G, Gresshoff PM: DNA amplification fingerprinting using arbitrary mini-hairpin oligonucleotide primers. Biotechnology (N Y) 1994;12:619-623.

33 Krapf R, Berry CA, Verkman AS: Estimation of intracellular chloride activity in isolated perfused rabbit proximal convoluted tubules using a fluorescent indicator. Biophys J 1988;53:955-962.

34 Chomczynski P, Sacchi N: Single-step method of RNA isolation by acid guanidinium thiocyanate-phenolchloroform extraction. Anal Biochem 1987;162:156-159.

35 Inoue H, Nojima H, Okayama H: High efficiency transformation of Escherichia coli with plasmids. Gene 1990;96:23-28.

36 Gussow D, Clackson T: Direct clone characterization from plaques and colonies by the polymerase chain reaction. Nucleic Acids Res 1989;17:4000. 


\section{Cellular Physiology Cell Physiol Biochem 2016;38:49-64

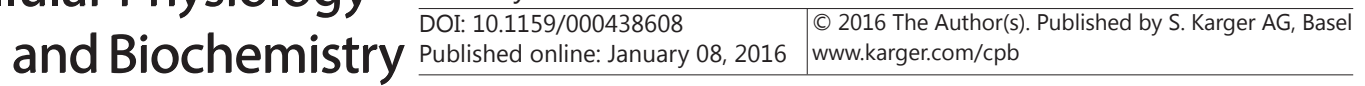 \\ Valdivieso et al.: Chloride Anion as a Second Messenger}

37 Altschul SF, Gish W, Miller W, Myers EW, Lipman DJ: Basic local alignment search tool. J Mol Biol 1990;215:403-410.

38 Altschul SF, Madden TL, Schaffer AA, Zhang J, Zhang Z, Miller W, Lipman DJ: Gapped BLAST and PSI-BLAST: a new generation of protein database search programs. Nucleic Acids Res 1997;25:3389-3402.

39 Sambrook J, Fritsch EF, Maniatis T: Molecular cloning, a laboratory manual, ed 2. New York, Cold Spring Harbor Laboratory Press, 1989, pp 7.43-7.45.

40 Ye J, Coulouris G, Zaretskaya I, Cutcutache I, Rozen S, Madden TL: Primer-BLAST: a tool to design targetspecific primers for polymerase chain reaction. BMC Bioinformatics DOI: 10.1186/1471-2105-13-134.

41 Fernandez-Pol JA: Conservation of multifunctional ribosomal protein metallopanstimulin-1 (RPS27) through complex evolution demonstrates its key role in growth regulation in Archaea, eukaryotic cells, DNA repair, translation and viral replication. Cancer Genomics Proteomics 2011;8:105-126.

42 Balcerczyk A, Gajewska A, Macierzynska-Piotrowska E, Pawelczyk T, Bartosz G, Szemraj J: Enhanced antioxidant capacity and anti-ageing biomarkers after diet micronutrient supplementation. Molecules 2014;19:14794-14808.

43 Aghaee-Bakhtiari SH, Arefian E, Soleimani M, Noorbakhsh F, Samiee SM, Fard-Esfahani P, Mahdian R: Reproducible and Reliable Real-time PCR Assay to Measure Mature Form of miR-141. Appl Immunohistochem Mol Morphol DOI: 10.1097/pai.0000000000000169.

44 Pilas B, Durack G: A flow cytometric method for measurement of intracellular chloride concentration in lymphocytes using the halide-specific probe 6-methoxy-N-(3-sulfopropyl) quinolinium (SPQ). Cytometry 1997;28:316-322.

45 Valdivieso AG, Marin MC, Clauzure M, Santa-Coloma TA: Measurement of cystic fibrosis transmembrane conductance regulator activity using fluorescence spectrophotometry. Anal Biochem 2011;418:231-237.

46 McWilliam H, Li W, Uludag M, Squizzato S, Park YM, Buso N, Cowley AP, Lopez R: Analysis Tool Web Services from the EMBL-EBI. Nucleic Acids Res 2013;41:W597-600.

47 Sigrist CJ, de Castro E, Cerutti L, Cuche BA, Hulo N, Bridge A, Bougueleret L, Xenarios I: New and continuing developments at PROSITE. Nucleic Acids Res 2013;41:D344-347.

48 Marchler-Bauer A, Lu S, Anderson JB, Chitsaz F, Derbyshire MK, DeWeese-Scott C, Fong JH, Geer LY, Geer RC, Gonzales NR, Gwadz M, Hurwitz DI, Jackson JD, Ke Z, Lanczycki CJ, Lu F, Marchler GH, Mullokandov M, Omelchenko MV, Robertson CL, Song JS, Thanki N, Yamashita RA, Zhang D, Zhang N, Zheng C, Bryant SH: CDD: a Conserved Domain Database for the functional annotation of proteins. Nucleic Acids Res 2011;39:D225-229.

49 Blom N, Gammeltoft S, Brunak S: Sequence and structure-based prediction of eukaryotic protein phosphorylation sites. J Mol Biol 1999;294:1351-1362.

50 Diella F, Cameron S, Gemund C, Linding R, Via A, Kuster B, Sicheritz-Ponten T, Blom N, Gibson TJ: Phospho.ELM: a database of experimentally verified phosphorylation sites in eukaryotic proteins. BMC Bioinformatics DOI: 10.1186/1471-2105-5-79.

51 Hornbeck PV, Chabra I, Kornhauser JM, Skrzypek E, Zhang B: PhosphoSite: A bioinformatics resource dedicated to physiological protein phosphorylation. Proteomics 2004;4:1551-1561.

52 Shukla A, Sharma P, Prakash O, Singh M, Kalani K, Khan F, Bawankule DU, Luqman S, Srivastava SK: QSAR and docking studies on capsazepine derivatives for immunomodulatory and anti-inflammatory activity. PLoS One DOI: 10.1371/journal.pone.0100797.

53 Fernandez-Pol JA, Fletcher JW, Hamilton PD, Klos DJ: Expression of metallopanstimulin and oncogenesis in human prostatic carcinoma. Anticancer Res 1997;17:1519-1530.

54 Ganger DR, Hamilton PD, Fletcher JW, Fernandez-Pol JA: Metallopanstimulin is overexpressed in a patient with colonic carcinoma. Anticancer Res 1997;17:1993-1999.

55 Santa Cruz DJ, Hamilton PD, Klos DJ, Fernandez-Pol JA: Differential expression of metallopanstimulin/S27 ribosomal protein in melanocytic lesions of the skin. J Cutan Pathol 1997;24:533-542.

56 Tsui SK, Lee SM, Fung KP, Waye MM, Lee CY: Primary structures and sequence analysis of human ribosomal proteins L39 and S27. Biochem Mol Biol Int 1996;40:611-616.

57 Tamir S, Paddock ML, Darash-Yahana-Baram M, Holt SH, Sohn YS, Agranat L, Michaeli D, Stofleth JT, Lipper CH, Morcos F, Cabantchik IZ, Onuchic JN, Jennings PA, Mittler R, Nechushtai R: Structure-function analysis of NEET proteins uncovers their role as key regulators of iron and ROS homeostasis in health and disease. Biochim Biophys Acta 2015;1853:1294-1315. 


\section{Cellular Physiology Cell Physiol Biochem 2016;38:49-64 \begin{tabular}{ll|l}
\hline and Biochemistry $10.1159 / 000438608$ & Published online: January 08, 2016 & $\begin{array}{l}\text { @ 2016 The Author(s). Published by S. Karger AG, Basel } \\
\text { www.karger.com/cpb }\end{array}$ \\
\hline
\end{tabular} \\ Valdivieso et al.: Chloride Anion as a Second Messenger}

58 Geldenhuys WJ, Leeper TC, Carroll RT: mitoNEET as a novel drug target for mitochondrial dysfunction. Drug Discov Today 2014;19:1601-1606.

59 Rodriguez-Manzaneque MT, Tamarit J, Belli G, Ros J, Herrero E: Grx5 is a mitochondrial glutaredoxin required for the activity of iron/sulfur enzymes. Mol Biol Cell 2002;13:1109-1121.

60 Johansson C, Roos AK, Montano SJ, Sengupta R, Filippakopoulos P, Guo K, von Delft F, Holmgren A, Oppermann U, Kavanagh KL: The crystal structure of human GLRX5: iron-sulfur cluster co-ordination, tetrameric assembly and monomer activity. Biochem J 2011;433:303-311.

61 Xie Y, Schafer JA: Inhibition of ENaC by intracellular Cl- in an MDCK clone with high ENaC expression. Am J Physiol Renal Physiol 2004;287:F722-731.

62 Treharne KJ, Crawford RM, Mehta A: CFTR, chloride concentration and cell volume: could mammalian protein histidine phosphorylation play a latent role? Exp Physiol 2006;91:131-139.

63 Roebler M, Müller V: Chloride, a new environmental signal molecule involved in gene regulation in a moderately halophilic bacterium, Halobacillus halophilus. J Bacteriol 2002;184:6207-6215.

64 Menegazzi R, Busetto S, Cramer R, Dri P, Patriarca P: Role of intracellular chloride in the reversible activation of neutrophil beta 2 integrins: a lesson from TNF stimulation. J Immunol 2000;165:4606-4614.

65 Prange HD, Shoemaker JL, Jr., Westen EA, Horstkotte DG, Pinshow B: Physiological consequences of oxygendependent chloride binding to hemoglobin. J Appl Physiol 2001;91:33-38.

66 Moriyama Y, Nelson N: The purified ATPase from chromaffin granule membranes is an anion-dependent proton pump. J Biol Chem 1987;262:9175-9180.

67 Pazoles CJ, Creutz CE, Ramu A, Pollard HB: Permeant anion activation of MgATPase activity in chromaffin granules. Evidence for direct coupling of proton and anion transport. J Biol Chem 1980;255:7863-7869.

68 Sangan P, Rajendran VM, Geibel JP, Binder HJ: Cloning and expression of a chloride-dependent Na+-H+ exchanger. J Biol Chem 2002;277:9668-9675.

69 Yuan A, Dourado M, Butler A, Walton N, Wei A, Salkoff L: SLO-2, a K+ channel with an unusual Cldependence. Nat Neurosci 2000;3:771-779.

70 Feller G, Bussy 0, Houssier C, Gerday C: Structural and functional aspects of chloride binding to Alteromonas haloplanctis alpha-amylase. J Biol Chem 1996;271:23836-23841.

71 Liu X, Fernandez M, Wouters MA, Heyberger S, Husain A: Arg(1098) is critical for the chloride dependence of human angiotensin I-converting enzyme C-domain catalytic activity. J Biol Chem 2001;276:3351833525 .

72 Nakajima T, Sugimoto T, Kurachi Y: Effects of anions on the G protein-mediated activation of the muscarinic $\mathrm{K}+$ channel in the cardiac atrial cell membrane. Intracellular chloride inhibition of the GTPase activity of GK. J Gen Physiol 1992;99:665-682.

73 Treharne KJ, Marshall LJ, Mehta A: A novel chloride-dependent GTP-utilizing protein kinase in plasma membranes from human respiratory epithelium. Am J Physiol 1994;267:L592-601.

74 Cigic B, Pain RH: Location of the binding site for chloride ion activation of cathepsin C. Eur J Biochem 1999;264:944-951.

75 Wolf-Watz M, Backstrom S, Grundstrom T, Sauer U, Hard T: Chloride binding by the AML1/Runx1 transcription factor studied by NMR. FEBS Lett 2001;488:81-84.

76 Shcheynikov N, Son A, Hong JH, Yamazaki O, Ohana E, Kurtz I, Shin DM, Muallem S: Intracellular Cl- as a signaling ion that potently regulates Na+/HCO3- transporters. Proc Natl Acad Sci U S A 2015;112:E329337.

77 Miyazaki H, Shiozaki A, Niisato N, Ohsawa R, Itoi H, Ueda Y, Otsuji E, Yamagishi H, Iwasaki Y, Nakano T, Nakahari T, Marunaka Y: Chloride ions control the G1/S cell-cycle checkpoint by regulating the expression of p21 through a p53-independent pathway in human gastric cancer cells. Biochem Biophys Res Commun 2008;366:506-512.

78 Ohsawa R, Miyazaki H, Niisato N, Shiozaki A, Iwasaki Y, Otsuji E, Marunaka Y: Intracellular chloride regulates cell proliferation through the activation of stress-activated protein kinases in MKN28 human gastric cancer cells. J Cell Physiol 2010;223:764-770. 